\title{
PENGARUH INFRASTRUKTUR TERHADAP PERTUMBUHAN EKONOMI DI JAWA TIMUR
}

\author{
Tony Sugiarto \\ Program Studi Pendidikan Ekonomi, Fakultas Ekonomi, Universitas Negeri Surabaya \\ Email : tonysugiarto@mhs.unesa.ac.id \\ Waspodo Tjipto Subroto \\ Program Studi Pendidikan Ekonomi, Fakultas Ekonomi, Universitas Negeri Surabaya \\ Email : waspodosubroto@unesa.ac.id
}

\begin{abstract}
Abstrak
Penelitian ini bertujuan untuk mengetahui pengaruh infrastruktur terhadap pertumbuhan ekonomi di Jawa Timur. Sampel dalam penelitian ini adalah PDRB di Jawa Timur periode 2007-2017. Teknik analisis yang digunakan dalam penelitian ini adalah analisis regresi linier berganda dengan menggunakan SPSS 23. Hasil penelitian ini menunjukan bahwa variabel Independen Infrastruktur Jalan, Jembatan, Listrik, Pendidikan dan Kesehatan tidak berpengaruh signifikan terhadap pertumbuhan ekonomi di Jawa Timur, namun ada hubungan positif antara variabel Independen dengan pertumbuhan ekonomi di Jawa Timur dengan tingkat kepercayaan variabel jalan sebesar 0,737. Jembatan sebesar 0,567. Listrik sebesar 0,024. Pendidikan sebesar 1,104. Dan kesehatan sebesar 0,478. Sedangkan secara simultan variabel jalan, jembatan, listrik, pendidikan dan kesehatan tidak berpengaruh secara signifikan dan berhubungan positif terhadap pertumbuhan ekonomi dengan nilai signifikan sebesar 3,174. Dengan nilai koefesien determinasi sebesar 0,760 .
\end{abstract}

Kata Kunci: Pengaruh Infrastruktur, Pertumbuhan Ekonomi

\section{Abstract}

The study aims to determine the effect of infrastructure on economic growth in Est Java. The sample in this study was GRDP in East Java for the period 2007-2017. The analysis technique used in this study is multiple linear regression analysis using SPSS 23. The results of this study indicate that the Independent variable of Road, Bridge, Electricity, Education and Health Infrastructure has no significant effect on economic growth in East Java, but there is a positive relationship between variables Independent of economic growth in East Java with a variable confidence level of 0.737 . The bridge is 0.567 . Electricity of 0.024 . Education equal to 1,104. And health of 0.478 . While simultaneously the variables of road, bridge, electricity, education and health did not significantly influence and positively related to economic growth with a significant value of 3.174. With the value of determination coefficient of 0.760 .

Keywords: Influence of Infrastructure, Economic Growth

\section{PENDAHULUAN}

Indonesia Negara kepulauan atau paling besar di

Dunia, Indonesia mempunyai rencana dalam pembangunan jangka panjang Nasional dengan didukung adanya rencana tata ruang wilayah secara Nasional yang menjadi panduan paling utama dalam pembangunanpembangunan Nasional hal ini sesuai dengan visi pembangunan Nasional tahun 2005 sampai tahun 2025 yang wajib dicapai yakni “ Indonesia Mandiri, Maju, makmur dan adil sesuai yang tertuang di dalam pembukaan perundangan Dasar Negara Republik Indonesia tahun 1945. (Waluyo, 2007:36)

Peningkatan mutu pembangunan Infrastruktur memanfaatkan sumber daya yang ada yang tidak terbatas dalam jumlah maupun kualitas yang sangat unggul, peningkatan sumber daya berkembang seiring dengan meningkatnya jumlah penduduk serta kebutuhan setiap penduduknya. Pemerintahan berperan penting sebagai mobilisator atau penyedia serta pendukung dalam hal pembangunan untuk terciptanya kesejahteraan masyarakat Indonesia serta terciptanya pertumbuhan ekonomi di setiap Negara khususnya di Indonesia. Pembangunan Infrastruktur suatu Negara bukti dari berkembangnya suatu Negara. Tiga alasan utama yang sangat penting dalam pembangunan Infrastruktur menurut integrasi ekonomi. yakni yang pertama, ketersediaan pembangunan Infrastruktur yang awal atau baru sangat utama dalam pembangunan pertumbuhan ekonomi. yang kedua, banyaknya ketersediaan 
pembangunan infrastruktur mempengaruhi dalam pelancar aktivitas investasi dan perdagangan yang terakhir bahwa perhatian yang penuh dalam hal perbaikan pembagunan dapat mengantisipasi infratruktur perekonomian antar Negara. (Friawan, 2008:142).

Dampak dari kurangnya pembangunan Infrastruktur yang memadai serta kualitas yang rendah bahkan kurangnya perawatan dalam partisipasi pembangunan Infrastruktur dapat menyebabkan perlambatan pertumbuhan ekonomi serta tenaga kerja yang tidak berkarakter, oleh sebab itu pembangunan Infrastruktur juga berperan dalam proses produksi dan sangat diperlukan oleh pemerintah dalam penarikan akumulasi modal sektor swasta dalam meningkatkan pertumbuhan ekonomi.

Alasan Pemerintah provinsi Jawa Timur membangun banyaknya infrastruktur di Jawa timur yaitu salah satunya untuk meningkatkan kesejahteraan bangsa serta masyarakatnya. pembangunan ini dimaksudkan dapat memperlancarkan perputaran ekonomi yang berasal dari dalam dan luar wilayah Jawa Timur. Infrastruktur untuk konektivitas difokuskan pada peningkatan Infrastruktur modal darat, laut dan udara serta pemeliharaan dan peningkatan jalan provinsi yang menjadi akses ke sentra produksi. (Ermine Jaen: 2018).

Kawasan selingkir wilis di Jawa Timur memiliki banyak potensi yang perlu dikembangkan seperti agrobisnis dan pariwisata dibutuhkanya pembangunan Infrastruktur yang mendukung pengembangan dalam kawasan tersebut, BPIW atau Badan Pengembangan Infrastruktur Wilayah, Kementrian Pekerjaan Umum Dan Perumahan Rakyat (PUPR) telah membuat perencanaan pengembanganya melalui pendekatan Wilayah pengembangan strategis (WPS). BPIW juga menggagas rapat koordinasi rencana tindak lanjut pengembangan selingkar Wilis. rapat yang dilakukan di kota Madiun dihadiri 6 kepala daerah dan juga 4 anggota komisi V DPR RI. Dalam pertemuan itu keterpaduan pun dilakukan untuk mengembangkan Infrastruktur PUPR di kawasan tersebut. (Sinergi Buleti Bpiw: 2017).

Pemerintah provinsi Jawa Timur berupaya meningkatkan pembangunan Infrastruktur di kawasankawasan yang mempunyai nilai besar bagi masyarakatnya dan yang berpengaruh pada pemerintahan sebab pembangunan Infrastruktur dapat menjadikan investasi bagi pemerintahan. tidak hanya jalan saja, pemerintah juga membangun jembatan sebagai fasilitas masyarakat yang membutuhkan, salah satunya jembatan yang ada di Surabaya yaitu jembatan Suramadu, Dibangunya jembatan Suramadu memberikan pengaruh besar untyuk kalangan masyarakat Madura khususnya daerah bangkalan salah satunya memberikan keringanan perjalanan yang jauh menjadi dekat tanpa naik kapal dan dapat memotong biaya dan menyingkat waktu perjalanan pelayanan ekonom.

Indikator berhasilnya pembangunan dalam Negara yaitu meningkatnya keberhasilan dari suatu pendidikan yakni kecerdasan bangsa dan kualitas dari detiap individu masyarakatnya. karena masyarakat yang cerdas diharapkan dapat bersaing dengan majunya global dimasa yang akan datang. pembangunan sarana fisik Infrastruktur sangat berkaitan dengan kesejahteraan dan proses pertumbuhan ekonomi suatu Negara yang mendukung peningkatan dalam hal produksi sektor perekonomian dan mendorong meningkatnya pertumbuhan ekonomi (Departemen Pekerja Umum, 2006).

Sementara Infrastruktur sosial dalam rangka memberikan pelayanan dasar kepada masyarakat diarahkan melalui program sanitasi dan air bersih, pada Badan Penanggulangan Bencana Daerah Provinsi Jawa Timur dan Dinas Perumahan Rakyat, Kawasan Permukiman dan Cipta Karya Provinsi Jawa Timur. Pertumbuhan ekonomi di Jawa Timur diakui melebihi rasio Nasional. apalagi pertumbuhan ekonomi untuk Kabupaten atau Kota yang sangat pesat yakni Banyuwangi. Selain dalam hal sanitasi air bersih dalam Infrastruktur sosial juga ada pendidikan. pendidikan ditunjukan bagi semua warga yang ada di Indonesia, semua masyarakat diharapkan bisa menikmati pendidikan secara merata baik masyarakat golongan atas, menengah dan kebawah, segala upaya dilakukan pemerintah untuk menunjang fasilitas pendidikan, banyak anggaran atau APBN yang ditunjukan pemerintah dalam hal pendidikan. karena tujuan pendidikan untuk mencerdaskan masyarakat bangsa.

Menurut Canning dan Pedroni (2004) menyatakan bahwa pengaruh tersedianya infrastruktur sangat penting dalam pertumbuhan ekonomi jangaka panjang, pembangunan infrastruktur juga sangat berpengaruh dengan kesejahteraan masyarakat. Tujuan utama diadakanya pelaksanaan dalam hal perekonomian yaitu terciptanya kondisi masyarakat yang sejahtera dikehidupan yang lebih baik, dapat memnuhi kebutuhan pangan serta kebutuhan materi baik dalam hal sosial serta terjaminya dalam hal keamanan. (Suciati, dkk, 2012:57).

Di dalam penelitian ini dapat diketahui bahwa jalan, jembatan, listrik, pendidikan dan kesehatan sangat dibutuhkan kalangan masyarakat dalam menjalankan aktivitas ekonominya. Peningkatan mutu pembangunan Infrastruktur memanfaatkan sumber daya yang ada yang tidak terbatas dalam jumlah maupun kualitas yang sangat unggul, peningkatan sumber daya berkembang seiring dengan meningkatnya jumlah penduduk serta kebutuhan setiap penduduknya. Pemerintahan berperan penting sebagai mobilisator atau penyedia serta pendukung dalam 
hal pembangunan untuk terciptanya kesejahteraan masyarakat Indonesia serta terciptanya pertumbuhan ekonomi di setiap Negara khususnya di Indonesia.

Pembangunan Infrastruktur suatu Negara bukti dari berkembangnya suatu Negara. Tiga alasan utama yang sangat penting dalam pembangunan Infrastruktur menurut integrasi ekonomi. yang pertama, ketersediaan pembangunan Infrastruktur yang awal atau baru sangat utama dalam pembangunan pertumbuhan ekonomi. yang kedua, banyaknya ketersediaan pembangunan infrastruktur mempengaruhi dalam pelancar aktivitas investasi dan perdagangan yang terakhir bahwa perhatian yang penuh dalam hal perbaikan pembagunan dapat mengantisipasi infratruktur perekonomian antar Negara. (Friawan, 2008:142).

Dampak dari kurangnya pembangunan Infrastruktur yang memadai serta kualitas yang rendah bahkan kurangnya perawatan dalam partisipasi pembangunan Infrastruktur dapat menyebabkan perlambatan pertumbuhan ekonomi serta tenaga kerja yang tidak berkarakter, oleh sebab itu pembangunan Infrastruktur juga berperan dalam proses produksi dan sangat diperlukan oleh pemerintah dalam penarikan akumulasi modal sektor swasta dalam meningkatkan pertumbuhan ekonomi.

Data jalan yang digunakan dalam penelitian ini meliputi panjang jalan Nasional keadaan baik dan sedang, jembatan nasional dalam keadaan baik dan sedang yang lebih dari $2 \mathrm{M}$. Dalam pembangunan Infrastruktur jalan pemerintah menganggarkan biaya yang cukup besar. dana alokasi khusus atau DAK dialokasikan anggaran dalam hal anggaran pendapatan belanja Negara (APBN) guna membiyayai bermacam kegiatan pembangunan infrastruktur, tujuannya dapat mengurangi berbagai permasalahan pelayanan publik dalam daerah dalam mobilitas sumber daya nya. Infrastruktur merupakan salah satu bidang penerima DAK terbesar selain kesehatan dan pendidikan, DAK merupakan dan Inpres (intruksi presiden) yang sudah berkembang dalam masa pemerintahan orde baru. (Entatarina, 2014:34-35).

Ketentuan yang berkaitan dengan system perencanaan pembangunan jalan sebagai berikut:

1) Dalam suatu kawasan jaringan jalan harus menunjukan jaraingan jalan yang sangat jelas anatara jalan lokal dan jalan utama yang berorientasi di kawasan fungsional yang terstruktur dengan baik, 2) Penghubungan antara peran jaringan jalan berfungsi di kawasan yang sudah ditetapkanya oleh pihak pemerintah kota maupun kabupaten, 3)Tertatanya ruang bangunan baik penataan elemen-elemen pada lingkungan penghijauan, 4)Pemeliharaan bahan pelapis jalan yang bagus yang mendukung lingkungan yang diinginkan serta kejelasan kontinuitas pejalan kaki. (Ajisasmita, 2012:91).

Data jembatan yang diambil dalam penelitian ini yaitu panjang jembatan Nasional keadaan baik-sedang dengan panjang > 2 meter. Penurunan permukaan jembatan berdampak pada kemacetan lalu lintas yang tidak dapat dihindari karena hanya 1 jalur jembatan saja bisa dilalui, stabilitas perekonomian disekitarnya, (Disa, 2016:5). Pengelompokan jembatan digolongkan sebagai berikut: Pertama, jembatan tetap atau disebut juga jembatan yang asli atau jembatan permanen guna bisa dimanfaatkan dalam jangka panjang. Kedua, jembatan yang tidak permanen jembatan yang digerakkan ini karna adanya transportasi yang melintasi jembatan tersebut bahan umumnya terbuat dari komposit dan baca karena bersifat mudah dalam kegiatan oprasionalnya.

Listrik yang digunakan dalam penelitian ini yaitu listrik yang telah dikonsumsi Kwh. Infrastruktur dalam hal kelistrikan yang sudah dikonsumsi masyarakat hal ini menunjukan bahwa semakin besar penggunaan energi listrik yang membantu dalam menggerakan perekonomian disuatu Negara, penggunaan sumber kelistrikan berperan penting guna meningkatnya produk Domestik Regional Bruto yang berdampak pada perekonomian di Indonesia karna dalam era ini listrik digunakan dalam kegiatan produksi serta kebutuhan rumah tanggah (Amalia, 2007).

Dalam infrastrukrur Pendidikan dan kesehatan data yang diambil adalah jumlah lembaga pendidikan tingkat SMK dan SMA, lembaga kesehatan RSU, puskesmas dan Puskesmas pembantu yang tercatat di provinsi Jawa Timur. Pendidikan SMK dan SMA berbanding 67 dan 33 persen pada tahun 2011, 290 SMK Negeri sisanya 1.700 dari jumlah tersebut 22 persen yang terakreditasi baik. untuk itu, yang menjadi program Bupati/ Walikota adalah mendirikan pendidikan SMK, SMK mini, BLK plus dan poli teknik serta menitipkan siswa SMK di pendidikan poli teknik sipil dan politeknil. selain itu, pendidikan vokasional yang menjadikan siswa punya skill. pembangunan infrastruktur yang dilaksanakan di provinsi Jawa Timur berlangsung dengan pesat mulai dari adanya pembangunan jalan misalnya jalan tol dari Surabaya ke nganjuk, dan dimulainya pembangunan jalan tol di pasuruan. Infrastruktur sanitasi air dan infrastruktur umum.

Selain pendidikan, pembangunan infrastruktur kesehatan juga sangat penting dalam hal sosial, pemerintah juga berusaha penuh dalam menfasilitasi pembangunan kesehatan. menurut Todari di dalam bukunya Sjafii mengungkapkan bahwa "kesehatan memiliki arti yang sangat penting dalam hal peningkatan produktivitas, kesehatan dan pendidikan memiliki input serta outputnya hal ini mengakibatkan infrastuktur 
pendidikan dan infrastruktur kesehatan penting dalam hal perekonomian dikarnakan komponen pertumbuhan yang sangat vital dari pendidikan maupun kesehatan itu sendiri. (Suratmo, 2009).

Indikator berhasilnya pembangunan dalam Negara yaitu meningkatnya keberhasilan dari suatu pendidikan yakni kecerdasan bangsa dan kualitas dari detiap individu masyarakatnya. karena masyarakat yang cerdas diharapkan dapat bersaing dengan majunya global dimasa yang akan datang. pembangunan sarana fisik Infrastruktur sangat berkaitan dengan kesejahteraan dan proses pertumbuhan ekonomi suatu Negara yang mendukung peningkatan dalam hal produksi sektor perekonomian dan mendorong meningkatnya pertumbuhan ekonomi (Departemen Pekerja Umum, 2006).

Data pertumbuhan ekonomi yang digunakan dalam penelitian ini yaitu data PDRB tahun 2007 sampai tahun 2017. Menurut Kuznet (1966) menyatakan bahwa pertumbuhan ekonomi sebagai kenaikan jangka panjang dalam kemampuan suatu Negara untuk menyediakan semakin banyak jenis barang-barang ekonomi kepada penduduknya. Kemampuan ini tumbuh sesuai dengan kemajuan teknologi, dan penyesuaian kelembagaan dan ideologis dan penyesuaian kelembagaan ideologis yang diperlukanya. Faktor utama dalam menginginkan pertumbuhan ekonomi yaitu dengan munculnya bakat yang berkualitas, kemampuan dalam segala bidang, kualitas dari berbagai sumber yang diperlukan, kapasitas dan kecakapan, sikap dari seluruh masyarakat yang baik, adat istiadat yang berlaku, nilai serta tujuan yang terlaksana baik, dan motivasi serta struktur politik dan kelembagaan yang berkualitas. (Jhigan, 2013).

Alasan utama dalam mengembangkan pertumbuhan ekonomi ada 3 yaitu pertama akumulasi modal meliputi investasi yang ditanamkan pada tanah, sumber daya manusia dan peralatan fisik, kedua tumbuhnya kepadatan penduduk yang semakin lama semakin pesat sehingga mempengaruhi jumlah angkatan kerja ketiga yaitu kemajuan teknologi, semkain bertambah tahun maka semakin banyak pula gagasan gagasan para ilmuwan dalam menciptakan bnayak teknologi canggi yang digunakan dalam aktivitas seharihari.

Pada model pertumbuhan solow menekankan betapa penting peran investasi dalam proses akumulasi model fisik. Peranan infrastruktur sangat berpengaruh dalam pertumbuhan ekonomi dalam setiap Negara. Daerah yang memiliki infrastruktur baik mempengaruhi pesat pertumbuhan ekonomi yang baik pula.

Fungsi pembangunan pada daerah berkembang dapat dijalankan ketika masyarakatnya dalm kondisi melemah dan bisa dikontrol dengan baik ketika masyarakatnya mulai membaik yaitu mencapai taraf yang lebih sejahtera. selain itu pemerintah berfungsi sebagai fungsi alokasi yaitu pemerintah sebagai penyedia barang dan jasa public, sebagai berikut: 1. pembangunan jalan raya, 2. pembangunan jembatan, 3. pembangunan fasilitas umum seperti: penerangan, telepon umum, tempat ibadah dan lain sebagainya. ( Faizal, Henry, 2008: 109).

Tujuan penelitian ini yaitu sebagai berikut: 1.Untuk mendeskripsikan pengaruh dari Infrastruktur jalan, jembatan dan listrik terhadap perekonomian di wilahaya Jawa Timur, 2.Untuk mendeskripsikan pengaruh Infrastruktur Pendidikan, kesehatan terhadap pertumbuhan perekonomian di wilayah Jawa timur.

\section{METODE}

Jenis penelitian ini yaitu penelitia kuantitatif yang proses penggalian informasi dalam bentuk angka-angka sebagai alat menemukan jawaban mengenai apa yang diketahui .(Margono, 2001:105). Pendekatan ini bermaksud untuk mengetahui hasil bahwa infrastruktur jalan, jembatan, listrik, pendidikan dan kesehatan apakah mempunyai pengaruh terhadap pertumbuhan ekonomi di Jawa Timur. yang akan diperoleh signifikan perbedaan kelompok atau signifikan hubungan antar variable yang akan diteliti, penelitian kuantitatif merupakan penelitian sampel besar.

Berikut ini adalah rancangan penelitian yang akan dilakukan oleh peneliti:

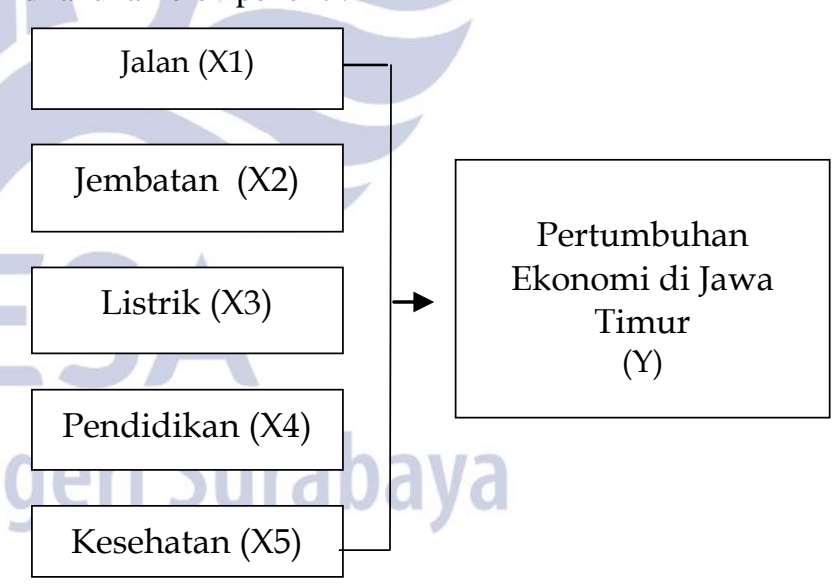

Gambar 1.1 kerangka berpikir konseptual

Untuk memperoleh data diperlukan sumber data primer dan sekunder. Sumber data primer dalam penelitian ini yaitu data yang diperoleh dari Publikasi BPS Jawa Timur. sedangkan data sekunder diperoleh berupa tersusun dalam data maupun dokumen-dokumen, pustaka dan jurnal-jurnal yang bersangkutan. Teknik analisis data menggunakan Analisa Regresi Berganda, Uji Asumsi Klasik, dan uji hipotesis. 


\section{Hasil dan Pembahasan}

Data yang digunakan dalam penelitian ini adalah data sekunder berupa time series data yang tercatat pada tahun 2007 sampai tahun 2017, data tersebut diperoleh dari Badan Pusat Statistik (BPS) provinsi Jawa Timur. data yang dimaksud meliputi panjang jalan Nasional keadaan baik dan sedang, jembatan nasional dalam keadaan baik dan sedang yang lebih dari $2 \mathrm{M}$, listrik yang dikonsumsi, lembaga pendidikan tingkat SMK dan SMA, lembaga kesehatan RSU, puskesmas dan Puskesmas pembantu yang tercatat di provinsi Jawa Timur dan dari data BPS.

Data dari variabel bebas yang diperoleh dari BPS yang telah dipublikasikan dapat diketahui bahwa panjang jalan Nasional dalam kondisi baik, sedang., jembatan Nasional, listrik yang dikonsumsi, pendidikan dan kesehatan mengalami peningkatan yang ridak signifikan dikarenakan adanya alasan tertentu dari provinsi Jawa Timur. sedangkan variabel bebas yakni dari data PDRB tahun 2007 sampai tahun 2017 yang diperoleh dari Badan Pusat Statistik mendapatkan hasil bahwa PDRB tiap tahunya mengalami kenaikan dan dapat dilihat pada tahun 2017 PDRB mencapai 148.214,806 tumbuh tinggi disbanding tahun sebelumnya. hal ini didorong oleh berbagai faktor yang ada termasuk faktor infrastruktur.

Hasil uji normalitas menunjukkan bahwa data menyebar disekitar garis diagonal dan mengikuti arah garis diagonal maka model regresi memnuhi asumsi normalitas.

Hasil uji Multikolonieritas menghasilkan Nilai VIF infrastruktur jalan 1,109 dan tolerance 0,902 nilai VIF infrastruktu jembatan 6,078 dan tolerance 0,165 , Nilai VIF Infrastruktur listrik 3,067 dan tolerance 0,326, Nilai VIF infrastruktur pendidikan 29,088 dan tolerance 0,034, Nilai VIF infrastruktur kesehatan 21,457 dan tolerance 0,047 karena nilai VIF dari kelima variabel melebihi $10 \%$ maka dapat dikatakan terjadi multikolonieritas.

Hasil uji heteroskedastisitas dapat dilihat jika titik-titik menyebar diatas dan dibawah angka 0 pada sumbuh $\mathrm{Y}$ tanpa membentuk pola tertentu, maka tidak terjadi heteroskedasitas. hal ini berarti asumsi klasik tentang heteroskedasitas telah terpenuhi yaitu terbebas dari heteroskedasitas.

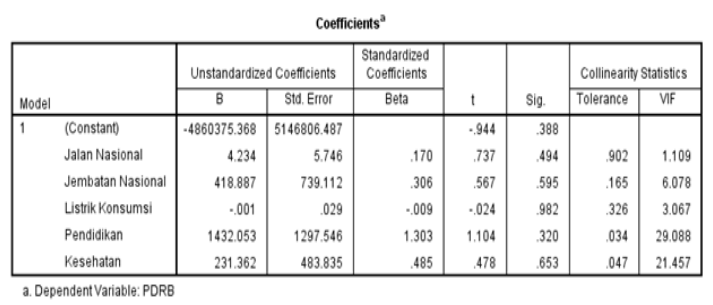

Sumber: Data diolah oleh peneliti 2019
Nilai $\mathrm{t}$ menunjukkan bahwa $\mathrm{X} 1$ memiliki $\mathrm{t}$ hitung sebesar 0,737 dengan $\mathrm{t}$ tabel sebesar 1,943 dapat dikatakan bahwa tidak memiliki nilai signifikan. Sedangkan X2 memiliki t hitung 0,567 dengan t tabel 1,943 dengan demikian diketahui bahwa X2 tidak memiliki nilai yang signifikan, X3 memiliki t hitung sebesar 0,024 dan t tabel sebesar 1,943 artinya tidak memiliki nilai yang signifikan, $\mathrm{X} 4$ memiliki t hitung 1,104 dan t tabel 1,943 yang artinya tidak memiliki nilai yang signifikan dan X5 memiliki t hitung sebesar 0,478 dan $\mathrm{t}$ tabel sebesar 1,943 artinya X5 tidak memiliki nilai yang signifikan.

Berdasarkan hasil perhitungan diatas ditentukan bahwa $\mathrm{f}$ hitung $<\mathrm{f}$ tabel $(3,174<5,05)$ dengan demikian ho diterima yang artinya baik infrastruktur jalan, jembatan, listrik, pendidikan dan kesehatan tidak berpengaruh positif terhadap PDRB (Y) di provinsi Jawa Timur dengan tingkat kepercayaan $95 \%$.

\section{Pembahasan Pengaruh Infrastruktur jalan terhadap pertumbuhan ekonomi}

Dari hasil pengujian hipotesis dapat diketahui bahwa jalan tidak berpengaruh secara signifikan dan berhubungan positif terhadap PDRB di Jawa Timur. dalam hal ini keberadaan infrastruktur jalan masih mengalami banyak kendala yaitu seperti badan jalan yang selalu mengalami kemacetan dimana hal ini dikarenakan pertumbuhan kendaraan yang tinggi dan banyaknya aktivitas manusia yang menggunakan kendaraan pribadi, kedua badan jalan yang dijadikan tempat parker secara liar dan para pedagang kaki lima yang tidak mempunyai izin resmi dari pemerintah sehingga mengganggu para pengendara kendaraan bermotor dan menyebabkan kemacetan, ketiga, badan jalan di wilayah Jawa Timur yang masih perlu mengalami perbaikan yang optimal, dan adanya bencana alam yang tidak diinginkan sehingga berdampak pada kondisi jalan yang mengalami kerusakan dan perlunya perbaikan infrastruktur jalan khususnya jalan nasional di wilayah Jawa Timur yang tidak efesien untuk pertumbuhan PDRB.

Hasil penelitian ini sejalan dengan penelitian yang dilakukan safitri (2018) yaitu jumlah kendaraan bermotor yang sudah terdaftar di daerah istimewa Yogyakarta dari tahun ke tahun selalu meningkat sehingga kondisi jalan yang rusak sebagian besar terjadi pada jalan-jalan kabupaten/ kota sehingga menyebabkan tidak efesien penyaluran hasil produksi. juga beberapa tahun yang lalu tepatnya tanggal 27 mei tahun 2006 terjadi gempa bumi yang mengguncang daerah tersebut yang berdampak terhadap infrastruktur dan mengalami kerussakan hingga saat ini banyak jalan yang butuh 
perbaikan ulang dengan tragedy tersebut menyebabkan adanya penambahan jalan dan tidak efesien dalam pertumbuhan PDRB di wilayah tersebut.

\section{Pengaruh Infrastruktur jembatan terhadap pertumbuhan ekonomi}

Dari hasil pengujian hipotesis dapat diketahui bahwa jembatan tidak berpengaruh secara signifikan dan berhubungan positif terhadap PDRb di Jawa Timur. dalam hal ini keberadaan infrastruktur jembatan masih mengalami banyak kendala yaitu seperti banyaknya terjadi tindakan criminal karena panjang jembatan yang terlalu panjang dan dalam keadaan sepi serta kurangnya pengawasan, jembatan yang roboh karena overload yang menyebabkan pihak pemerintah turun tangan dan membenahi jembatan sehingga berkurangnya anggaran infrastruktur yang membludak dan perawatan atas infrastruktur khususnya infrastruktur jembatan kurang pantauan sehingga jembatan nasional dii wilayah Jawa Timur yang tidak efesien untuk pertumbuhan PDRB.

Hasil penelitian ini tidak sama dengan penelitian tan dan achmad (2013) yang menghasilkan penelitian bahwa infrastruktur jalan, jembatan, irigrasi dan pasar secara bersama mempunyai pengaruh positif dan signifikan terhadap nilai tambah pertumbuhan ekonomi di kabupaten muara jambi.

\section{Pengaruh Infrastruktur listrik terhadap pertumbuhan ekonomi}

Dari hasil penelitian dapat diketahui bahwa infrastruktur pendidikan tidak mempengaruhi secara signifikan dan memiliki hubungan yang positif terhadap pertumbuhan ekonomi di Jawa Timur. dalam hal ini keberadaan infrastruktur pendidikan di Jawa Timur masih perlu adanya pengawasan dan tanggung jawab bagi pemerintah dan pihak terkait terhadap para siswa yang kurang mampu, karena kebanyakan lembaga pendidikan negeri biaya pendidikan ditanggung oleh pemerintah dan pemerintah juga masih banyak menangani kasus kurangnya biaya bagi peserta didik yang kurang mampu. sehingga tidak adanya pengaruh infrastruktur terhadap pertumbuhan ekonomi di Jawa Timur.

Hal ini sama dengan penelitian yang dilakukan oleh Fauzi (2017) yangmenghasilkan kesimpulan bahwa pendidikan tidak berpengaruh secara signifikan terhadap pertumbuhan ekonomi di tahun yang sama dan dua tahun berikutnya, hal ini diduga dikarenakan realisasi belanja bidang pendidikan banyak menumpuk diakhir tahun, sehingga dampaknya tidak langsung dilihat di tahun berjalan.

\section{Pengaruh Infrastruktur pendidikan terhadap pertumbuhan ekonomi}

Dari hasil penelitian dapat diketahui bahwa infrastruktur pendidikan tidak mempengaruhi secara signifikan dan memiliki hubungan yang positif terhadap pertumbuhan ekonomi di Jawa Timur. dalam hal ini keberadaan infrastruktur pendidikan di Jawa Timur masih perlu adanya pengawasan dan tanggung jawab bagi pemerintah dan pihak terkait terhadap para siswa yang kurang mampu, karena kebanyakan lembaga pendidikan negeri biaya pendidikan ditanggung oleh pemerintah dan pemerintah juga masih banyak menangani kasus kurangnya biaya bagi peserta didik yang kurang mampu. sehingga tidak adanya pengaruh infrastruktur terhadap pertumbuhan ekonomi di Jawa Timur.

Hal ini sama dengan penelitian yang dilakukan oleh Fauzi (2017) yangmenghasilkan kesimpulan bahwa pendidikan tidak berpengaruh secara signifikan terhadap pertumbuhan ekonomi di tahun yang sama dan dua tahun berikutnya, hal ini diduga dikarenakan realisasi belanja bidang pendidikan banyak menumpuk diakhir tahun, sehingga dampaknya tidak langsung dilihat di tahun berjalan.

Pengaruh Infrastruktur kesehatan terhadap pertumbuhan ekonomi

Pembangunan infrastruktur kesehatan tidak berpengaruh signifikan namun berhubungan positif terhadap pertumbuhan ekonomi di Jawa Timur dikarenakan hasil data dari lembaga kesehatan masih kurang memadai bagi penunjang PDRB di Jawa Timur. hal ini sama dengan penelitian yang telah dilakukaan Fauzi (2017) menerangkan jika infrastruktur kesehatan tidak ada pengaruh terhadap pertumbuhan ekonomi di kabupaten atau kota provinsi lampung.

\section{PENUTUP}

\section{Kesimpulan}

Dari hasil penelitian yang diperoleh dapat disimpulkan bahwa Infrastruktur Jalan, Jembatan, Listrik, Pendidikan dan kesehatan tidak berpengaruh secara signifikan terhadap pertumbuhan ekonomi di Jawa Timur.

\section{Saran}

Saran yang dapat saya sampaikan adalah 1 . Pemerintah daerah harus benar-benar menyadari bahwa infrastruktur jalan merupakan indicator yang penting dan mampu memacu tingkat pertumbuhan ekonomi jika dikelolah dengan baik dan benar agar sektor-sektor ekonomi yang ada di Jawa Timur terus mengalami peningkatan yang lebih baik, 2. Infrastruktur jembatan 
sebagai bagian penting dalam pemanfaatan jalan yang menghubungkan antar wilayah atau daerah yang seharusnya menjadi perhatian khusus bagi pemerintah untuk kesejahteraan masyarakat khususnya di wilayah Jawa Timur sehingga nantinya bisa memberikan kesejahteraan untuk masyarakat dan bisa menambah peningkatan pertumbuhan ekonomi di Jawa Timur, 3. Infrastruktur listrik merupakan infrastruktur yang tidak kalah penting dengan infrastruktur lainya yang berguna bagi masyarakat di Jawa Timur, oleh karena itu pemerintah diharapkan mampu meningkatkan infrastruktur listrik dan dapat mengelolah dengan baik dan benar sehingga menghasilkan pengaruh dalam opertumbuhan ekonomi di Jawa Timur, 4. Infrastruktur pendidikan merupakan infrastruktur yang dibutuhkan oleh semua kalangan masyarakat untuk menghadapi kemajuan globalisasi di masa yang akan datang, pemerintah seharusnya memperhatikan bahwa hasil dari pendidikan dapat menjadikan atau menciptakan generasi yang lebih maju sehingga dapat difungsikan sebagai alat untuk memajukan pertumbuhan perekonomian di Jawa Timur, 5. Hendaknya infrastruktur kesehatan lebih ditingkatkan lagi, terutama di daerah pelosok yang ada di Jawa Timur, kualitas kesehatan selalu terjaga agar dapat memenuhi hidup dan kehidupan yang lebih baik sehingga dapat meningkatkan pertumbuhan perekonomian di Jawa Timur.

\section{DAFTAR PUSTAKA}

Adisasmita, Adji (2010). Dasar-Dasar Ekonomi Wilayah. Yogyakarta: Media Genius.

Amalia, Lia (2007). Ekonomi Pembangunan. Yogyakarta : Graha Ilmu.

Disa Fahmi. (2016), Analisis Paket Pekerjaan Penggantian Jembatan Dengan Box Culvert Studi Kasus: Ruas Batu Licin-Sei. 2(01).

Faizal Noor, Henry (2008),Ekonomi Manajerial. PT.Raja Grafindo : Jakarta.

Friawan, Deni (2008). Kondisi Pembangunan Infrastruktur di Indonesia. CSIS Vol.2/37. Jakarta: Lembaga Penerbit Fakultas Ekonomi Universitas Indonesia.

Suciati, D. A.P., Budhi, M. K.S., dan Jayastra, K. (2015). Pengaruh Jumlah Penduduk, Dana Perimbangan Dan Investasi Pada Kesejahteraan Masyarakat Melalui Belanja Langsung Pada Kabupaten/Kota Di Provinsi Bali Tahun 2007-2012.20(2). 83-93. Diperoleh pada 28 Juli 2018, dari Jurnal Buletin Studi Ekonomi.

Suratmo, F. Gunawan (2009). Analisis Mengenai Dampak Lingkungan. Yogyakarta: Selemba Empat.
Waluyo, Joko (2008). Hubungan Antara Tingkat Kesenjangan Pendapatan Dengan Pertumbuhan Ekonomi: Suatu Study Lintas Negara. 3(2). Dalam Jurnal Ekonomi Pembangunan Kajian Ekonomi Negara Berkembang. 